\title{
Montgrí, a Cultivar within the Montserrat Tomato Type
}

Joan Casals, Lluís Bosch, and Francesc Casañas ${ }^{1}$

Departament d'Enginyeria Agroalimentària i Biotecnologia, Universitat Politècnica de Catalunya, Campus del Baix Llobregat, Avda. Canal Olímpic 15, 08860 Castelldefels, Spain

\section{Jaime Cebolla and Fernando Nuez \\ Instituto Universitario de Conservación y Mejora de la Agrodiversidad Valenciana, Universidad Politécnica de Valencia, Camino de Vera 14, 46022 Valencia, Spain}

Additional index words. tomato landrace, breeding, genealogic method, sensory analysis, Montserrat

Montserrat is a tomato (Solanum lycopersicum) landrace of Marmande-type (Philouze, 1991) that is widely cultivated in Catalonia (northeast Spain). It is medium-sized, markedly ribbed, and has hollow spaces in the seed cavity. There are two morphological variants, a flattened one that gives its name to the more common landrace (Montserrat) and a pyriform one (Pera Girona). The two variants have distinct markets and form part of the Catalan gastronomic tradition, being important in numerous local dishes (salads, sauces, stuffed tomatoes). Local farmers carry out their own selections, thus preserving the genetic variability in situ. However, in recent years, introgressions from other traditional and/or improved cultivars have resulted in numerous transitional forms. We began a breeding program to obtain a prototypical cultivar of Pera Girona within the Montserrat landrace that would fulfill consumers' organoleptic demands, maintain the typical shape, and have good agronomic behavior while ensuring the homogeneity necessary in today's marketplace. The result we present here is a cultivar that respects the morphological characteristics of the fruit, has a superior organoleptic quality, and a low susceptibility to blossom-end rot (BER).

\section{Origin}

After exhaustively collecting Pera Girona materials (only pyriform variants of Montserrat) from farmers in the traditional area of cultivation, we obtained 62 accessions and characterized them according to their agronomic, morphological, and sensory traits. Together with surveys of farmers and consumers, this analysis enabled us to define an ideotype that would combine the relevant sensory characteristics (balanced sweetness/acidity with medium/high levels of both; low skin per-

\footnotetext{
Received for publication 25 May 2010. Accepted for publication 23 Aug. 2010.

This study was funded by the Department of Agriculture, Food, and Rural Action of the Autonomous Government of Catalonia.

${ }^{1}$ To whom reprint requests should be addressed; e-mail francesc.casanas@upc.edu.
}

ception and low pericarp mealiness; marked ribbing; intermediate hollowness of the seed cavity; and high pericarp thickness) with acceptable agronomic behavior (good yields; homogeneity of fruit size; and low susceptibility to BER).

None of the accessions studied had high scores for all desired traits, so we designed a breeding program based on the genealogical method applied to the variability generated by crossing materials that had complementary traits (Allard, 1999). We selected six lines with good scores for the ideotype descriptors and performed a diallel crossing among all of them (15 crosses). From the 15 hybrids obtained, we selected the one closest to the ideotype to produce $\mathrm{F}_{2}$, from which we selected 80 plants to produce descendents by self-fertilization. From each of these $80 \mathrm{~F}_{3} \mathrm{~s}$, we planted 40 plants, selecting between and within families in generations $\mathrm{F}_{3}$ to $\mathrm{F}_{5}$ (the selection pressure was $2 \%$ in each generation). Montgrí was chosen as the best genotype in the $\mathrm{F}_{6}$ gener- ation (seeds were harvested from a single plant), especially for its high sensory profile. The descendents of this material $\left(\mathrm{F}_{7}\right.$ and $\left.\mathrm{F}_{8}\right)$ were cultivated in four locations (Sabadell, Castellar del Vallès, Palafolls, and Calella) during 2 years (2005 and 2006) to evaluate their stability and homogeneity.

\section{Description}

Montgrí tomatoes (Fig. 1) are of intermediate weight (160 g to $210 \mathrm{~g}$ ), pyriform with a slightly indented blossom end, multilocular (five or more locules), with pronounced ribs, green shoulder, pink exterior [presence of $y$ gene (Ballester et al., 2010)], and red flesh. They have a thick pericarp and low level of seed cavity hollowness compared with the mean of the Pera Girona type. The plant has indeterminate growth with intermediate foliage density; the first truss is high $(58 \mathrm{~cm})$ and the inflorescence is usually uniparous (mean 1.3 branches and 3.5 fruits in the third truss). Disease resistance has not been found either for this line or for the Pera Girona type.

From May to Oct. 2007 we cultivated Montgrí, its parents (CDP02518, CDP05564), two widely grown accessions with Pera Girona morphology (CDP08823, CDP09437), and the commercial hybrid most widely grown in the traditional area of cultivation of Pera Girona (Bodar, Royal Sluis S.L.) in the open air. The cultivar Montgrí scored well for all agronomic and morphologic traits, obtaining values similar to or better than the best parent for each trait (Table 1$)$. The yield ( $4.5 \mathrm{~kg} /$ plant) was similar to that of its parent, CDP05564 $(4.7 \mathrm{~kg}$ / plant), and significantly higher than that of its other parent, CDP02518 (3.7 kg/plant) (Table $1)$. The incidence of BER (1.5\%) was significantly lower than those reported for the other Pera Girona accessions and not different from that of the hybrid Bodar (Table 1). This finding is important because BER can cause significant

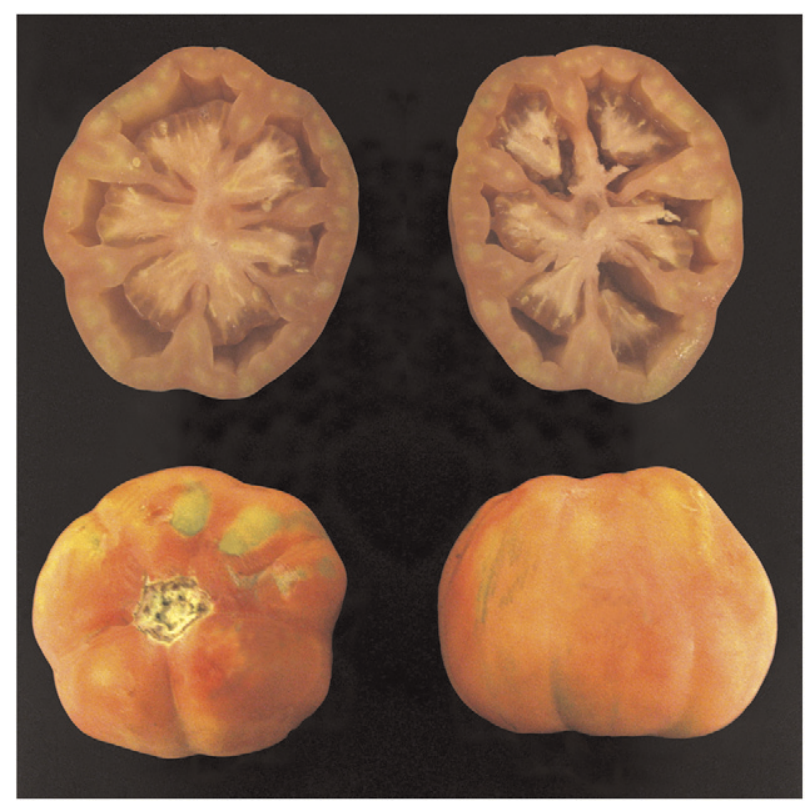

Fig. 1. Montgrí fruits: whole and cross-section. 
Table 1. Agronomic performance and morphological traits for Montgrí, selected inbred lines (CDP02518, CDP05564), controls of Pera Girona type (CDP08823, CDP09437), and Bodar. ${ }^{2}$

\begin{tabular}{lcccccc}
\hline Accession & $\begin{array}{c}\text { Yield } \\
(\mathrm{kg} / \mathrm{plant})\end{array}$ & $\begin{array}{c}\text { Fruit wt } \\
(\mathrm{g})\end{array}$ & $\begin{array}{c}\text { Fruit size } \\
\text { homogeneity }(\%)^{\mathrm{y}}\end{array}$ & $\begin{array}{c}\text { BER } \\
(\%)^{\mathrm{x}}\end{array}$ & $\begin{array}{c}\text { Relative thickness } \\
\text { of }^{\text {the pericarp }} \text { (n) }^{\mathrm{w}}\end{array}$ & $\begin{array}{c}\text { Hollowness of } \\
\text { the seed cavity }^{\mathrm{v}}\end{array}$ \\
\hline Bodar & $6.1 \mathrm{a}$ & $131.9 \mathrm{~d}$ & $22.9 \mathrm{~d}$ & $0.1 \mathrm{c}$ & $0.382 \mathrm{a}$ & - \\
CDP09437 & $3.0 \mathrm{~d}$ & $113.1 \mathrm{e}$ & $32.2 \mathrm{c}$ & $6.4 \mathrm{~b}$ & $0.119 \mathrm{~b}$ & $0.251 \mathrm{a}$ \\
CDP05564 & $4.7 \mathrm{~b}$ & $220.2 \mathrm{~b}$ & $49.8 \mathrm{a}$ & $6.0 \mathrm{~b}$ & $0.084 \mathrm{c}$ & $0.198 \mathrm{a}$ \\
CDP02518 & $3.7 \mathrm{~cd}$ & $251.3 \mathrm{a}$ & $39.9 \mathrm{~b}$ & $5.2 \mathrm{~b}$ & $0.127 \mathrm{~b}$ & $0.040 \mathrm{c}$ \\
CDP08823 & $4.3 \mathrm{bc}$ & $144.1 \mathrm{~d}$ & $42.5 \mathrm{~b}$ & $15.3 \mathrm{a}$ & $0.115 \mathrm{~b}$ & $0.128 \mathrm{~b}$ \\
Montgrí & $4.5 \mathrm{~b}$ & $182.8 \mathrm{c}$ & $38.9 \mathrm{~b}$ & $1.5 \mathrm{c}$ & $0.115 \mathrm{~b}$ & $0.087 \mathrm{bc}$ \\
\hline
\end{tabular}

${ }^{z}$ The traits and measurement techniques used were those proposed by the IPGRI (1996). A completely randomized block design was used with three blocks and 12 plants per plot. Mean values in a column followed by the same letter are not significantly different according to Duncan's multiple range test $(P \leq$ $0.05)$.

${ }^{y_{C V}}$ of the weight of fruits within a plant. Low values indicate greater homogeneity.

xPercentage of fruits affected by blossom-end rot (BER) per plant.

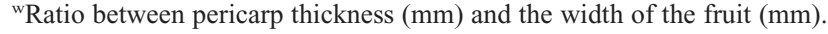

'Ratio between the width of the hollow part of the seed cavity (mm) and the width of the fruit (mm). All fruits of the Bodar cultivar had no hollow spaces in the seed cavity.

Table 2. Sensory and instrumental traits for Montgrí, selected inbred lines (CDP02518, CDP05564), controls of Pera Girona type (CDP08823, CDP09437), and Bodar. ${ }^{2}$

\begin{tabular}{|c|c|c|c|c|c|c|c|c|}
\hline Accession & $\begin{array}{c}\text { Skin } \\
\text { perception }\end{array}$ & $\begin{array}{l}\text { Pericarp } \\
\text { mealiness }\end{array}$ & Sweetness & Acidity & Taste & Odor & ${ }^{\circ}$ Brix & $\mathrm{pH}$ \\
\hline Bodar & $9.64 \mathrm{a}$ & $8.31 \mathrm{ab}$ & $3.66 \mathrm{~b}$ & $5.69 \mathrm{a}$ & $8.93 \mathrm{a}$ & $8.52 \mathrm{ab}$ & $4.04 \mathrm{bc}$ & $4.29 \mathrm{~b}$ \\
\hline CDP09437 & $6.08 \mathrm{~b}$ & $6.10 \mathrm{~b}$ & $3.15 \mathrm{~b}$ & $3.90 \mathrm{~b}$ & $4.55 \mathrm{c}$ & $8.87 \mathrm{a}$ & $4.25 \mathrm{bc}$ & $4.47 \mathrm{~b}$ \\
\hline CDP05564 & $6.16 \mathrm{~b}$ & $6.09 \mathrm{~b}$ & $3.42 \mathrm{~b}$ & $4.01 \mathrm{~b}$ & $5.87 \mathrm{bc}$ & $5.37 \mathrm{c}$ & $3.78 \mathrm{c}$ & $4.77 \mathrm{a}$ \\
\hline CDP02518 & $7.58 \mathrm{ab}$ & $8.74 \mathrm{a}$ & $3.59 \mathrm{~b}$ & $2.74 \mathrm{c}$ & $7.05 \mathrm{~b}$ & $8.21 \mathrm{ab}$ & $4.65 \mathrm{~b}$ & $4.79 \mathrm{a}$ \\
\hline CDP08823 & $6.48 \mathrm{~b}$ & $6.62 \mathrm{ab}$ & $3.06 \mathrm{~b}$ & $4.05 \mathrm{~b}$ & $3.26 \mathrm{c}$ & $6.24 \mathrm{bc}$ & $4.29 \mathrm{bc}$ & $4.56 \mathrm{ab}$ \\
\hline Montgrí & $6.19 \mathrm{~b}$ & $6.94 \mathrm{ab}$ & $5.21 \mathrm{a}$ & $3.69 \mathrm{~b}$ & $9.08 \mathrm{a}$ & $6.49 \mathrm{abc}$ & $5.36 \mathrm{a}$ & $4.41 \mathrm{~b}$ \\
\hline
\end{tabular}

${ }^{z}$ The analysis of variance included the fixed factors panelist and accession, the random factor session, and the interaction panelist*accession. Mean values in a column followed by the same letter are not significantly different according to Duncan's multiple range test $(P \leq 0.05)$. Sensory evaluations were done by a trained panel (eight judges) in a room specifically designed for this purpose (ISO 8589, 1988). Accessions were scored on a semistructured scale from 0 (low) to 10 (high) for all traits. The experimental design had five sessions and four accessions per session, and each accession was tested in triplicate. ${ }^{\circ} \mathrm{Brix}$ and $\mathrm{pH}$ were measured on the same samples presented to the panel.

losses in tomato crops (Taylor and Locascio, 2004), especially in Pera Girona-type tomatoes in their traditional area of cultivation. Montgrí was not significantly different from the bestscoring parent (CDP02518) on fruit size homogeneity (CV 38.9\%) and pericarp thickness $($ score $=0.115)($ Table 1). Finally, the hollowness of the seed cavity characteristic of the Montserrat cultivar was present in Montgrí but only slightly (score $=0.087$ in Table 1 ) as defined in the ideotype. The cultivars CDP09437 and CDP08823, widely grown by local farmers, showed poor agronomic results (CDP09437 is the accession with the lowest yield: $3.0 \mathrm{~kg} /$ plant and CDP08823 had the highest incidence of BER, $15.3 \%$, and low fruit size homogeneity, $42.5 \%$ ) (Table 1). This underlines the need for sweetness/acidity with medium acidity (score $=$ 3.69) and low $\mathrm{pH}(\mathrm{pH}=4.41)$ (Table 2). High sweetness, high intensity of taste, and balance between sweetness and acidity seem to be the attributes that are most appreciated by the average consumer (Debruyn et al., 1971; Stevens et al., 1977). Montgrí's scores for texture traits were similar to its parent CDP05564 and to the accessions CDP08823 and CDP09437 with low skin perception ( score $=6.19$ ) and low pericarp mealiness $($ score $=6.94)($ Table 2$)$. On the other hand, its sensory profile differed from that of Bodar, which is a markedly acidic tomato (low sweetness, score $=3.66$, and high acidity, score $=5.69$ ) with a mealy texture $($ score $=8.31)$ and high skin perception (score $=$ 9.64) (Table 2).

Montgrí seeds are now being grown on an experimental basis by farmers in the traditional area of production for Pera Girona. Small samples of Montgrí seeds are available for research purposes (please contact the author).

\section{Literature Cited}

Allard, R.W. 1999. Principles of plant breeding. 2nd Ed. John Wiley \& Sons Inc., New York, NY.

Ballester, A.R., J. Molthoff, R. de Vos, B. Lintel Hekkert, D. Orzaez, J.P. Fernández-Moreno, P. Tripodi, S. Grandillo, C. Martin, J. Heldens, M. Ykema, A. Granell, and A. Bovy. 2010. Biochemical and molecular analysis of pink tomatoes: Deregulated expression of the gene encoding transcription factor S1MYB12 leads to pink tomato fruit color. Plant Physiol. 152: 71-84.

Debruyn, J.W., F. Garretse, and E. Kooistra. 1971. Variation in taste and chemical composition of tomato (Lycopersicon esculentum, Mill.). Euphytica 20:214-227.

a breeding program to obtain better materials from local populations. However, as expected, Bodar obtained the best agronomic results with better yield $(6.1 \mathrm{~kg} /$ plant $)$, fruit size homogeneity $(22.9 \%)$, incidence of BER $(0.1 \%$ of fruit affected), and pericarp thickness (score $=0.382$ ) than the rest of the accessions (Table 1).

Nevertheless, the main goal of the breeding program was to obtain a cultivar with great organoleptic value. In this respect, Montgrí performed very well with significantly higher values for sweetness (score = 5.21 ), soluble solids $\left({ }^{\circ}\right.$ Brix $=5.36$ ), and intensity of taste (score $=9.08$ ) than the parents and other accessions of Pera Girona (Table 2). Moreover, Montgrí stood out for its balanced
IPGRI. 1996. Descriptors for tomato (Lycopersicon). International Plant Genetic Resources Institute, Rome, Italy.

ISO 8589. 1988. Sensory analysis-General guidance for the design of test rooms. International Organization for Standardization, Geneva, Switzerland.

Philouze, J. 1991. Description of isogenic lines, except for one, or two, monogenically controlled morphological traits in tomato, Lycopersicon esculentum Mill. Euphytica 56:121-131.

Stevens, M.A., A.A. Kader, M. Albrightholton, and M. Algazi. 1977. Genotypic variation for flavor and composition in fresh market tomatoes. J. Amer. Soc. Hort. Sci. 102:680-689.

Taylor, M.D. and J. Locascio. 2004. Blossom-end rot: A calcium deficiency. J. Plant Nutr. 27:123139. 